\title{
JE POJMOVÝ RELATIVIZMUS PREDPOKLADOM FILOZOFIE AKO POJMOVÉHO INŽINIERSTVA? ${ }^{1}$
}

PAVOL LABUDA, Katolícka univerzita v Ružomberku, Filozofická fakulta , Katedra filozofie, Ružomberok, SR

LABUDA, P.: Is Conceptual Relativism a Prerequisite for Philosophy as Conceptual Engineering?

FILOZOFIA, 76, 2021, No 1, pp. $3-17$

The aim of the paper is to examine whether conceptual relativism is a prerequisite for conceptual engineering (and if so, then to what extent). In the first part of the paper, I explore and classify varieties of relativism to prepare a distinctive definition of conceptual relativism. In the second part I analyse conceptual relativism and I consequently propose two different readings of conceptual scheme: (i) conceptual scheme as a monolithic, timeless, and determinate systems of meanings, and (ii) conceptual scheme as a system of relatively stable meanings, that is based on agreement and is open to change over time. In the third part of the paper, I show that of those two readings only the second reading of conceptual scheme fits into the practice of conceptual engineering.

Keywords: Relativism - Antirealism - Conceptual schemes - Concepts - Analysis Philosophy - Conceptual engineering - Language - Meaning change

\begin{abstract}
„Aby vnemová alebo pojmová skúsenost' bola pravdivá, musí zodpovedat' realite. ,Realitou' však [pragmatizmus] ... nemyslí nič viac, ako d’alšie pojmové a vnemové skúsenosti, s ktorými sa môže tá prebiehajúca skúsenost' zrazu objavit' v prepletenom výkone.“
\end{abstract}

William James: Pragmatism and the Meaning of Truth $(1975,225)$

\section{Úvod}

V predloženom článku sledujem dva ciele: 1) predstavit’ aktuálne sa rozvíjajúce hnutie, ktoré chápe filozofovanie ako pojmové inžinierstvo; 2) preskúmat', či (a ak áno,

\footnotetext{
${ }^{1}$ Ďakujem dvom anonymným recenzentom časopisu Filozofia a členom filozofického seminára Privatissimum na FF KU za to, že ma upozornili na viacero nedopracovaných momentov či vecných nejasností v pôvodnej verzii príspevku.
} 
tak do akej miery) je pojmový relativizmus predpokladom takéhoto chápania filozofie. Predtým, ako sa k plneniu týchto ciel'ov dostanem, objasním, čo rozumiem pod relativizmom, pojmovým relativizmom a pojmovým inžinierstvom. Mojim finálnym zámerom je obhájit' tézu, že pojmový relativizmus je nutným predpokladom filozofie ako pojmového inžinierstva, a zároveň objasnit', aké záväzky sa s obhajobou tejto tézy spájajú.

Argumentačná línia pre podporu mnou zastávanej tézy bude takáto. Pokúsim sa preukázat', že každý pojem je integrálnou súčast'ou určitej pojmovej schémy. Neexistuje absolútne, ale vždy len vzhladom na určitú pojmovú schému. Potom predstavím pojmové inžinierstvo ako filozofický projekt, ktorého ciel'om nie je len opis, ale aj zlepšovanie pojmov. Ak chce pojmové inžinierstvo nejaký pojem zlepšit', môže to uskutočnit' len v rámci určitej pojmovej schémy. Zlepšovanie pojmu teda predpokladá ideu revidovatel'nosti pojmových schém, ktorá počíta s relativitou ako internou vlastnost’ou pojmov v rámci každej jednej pojmovej schémy.

\section{Relativizmus}

Relativizmus je pomenovanie pre pomerne heterogénny súbor pozícií. Tento súbor drží (okrem tradície) pohromade nasledujúca trojica predpokladov: 1) čokol'vek, čo existuje, existuje vo vzt'ahu k určitému referenčnému rámcu; 2) jestvuje pluralita referenčných rámcov; 3) nejestvuje absolútne - teda od nejakého referenčného rámca nezávislé - kritérium rozhodovania medzi alternatívnymi ${ }^{2}$ referenčnými rámcami. Stručný a metodologicky precízne spracovaný prehl'ad rozličných druhov relativizmu ponúka Michael Krausz (2011). Rozlíšenie jednotlivých druhov relativizmu vykonáva za pomoci kombinácie piatich parametrov. Za pomoci výberu a) referenčného rámca (napr. pojmový, kultúrny, historický), b) oblasti (napr. morálnej, estetickej, právnej), c) roviny (ontická alebo epistemická), d) hodnoty (pravda, dobro, krása) a na základe e) typu absolutizmu, voči ktorému sa ten-ktorý druh relativizmu vymedzuje. ${ }^{3}$ Najmä posledný parameter spomenutý Krauszom pokladám za vhodný nástroj presnejšieho určenia druhu relativizmu, ktorý sa stane o chvílu hlavným predmetom mojej pozornosti. Podl'a metafory použitej Krauszom absolutizmus je mocným lanom upleteným z vláken, ktoré dokážu stát i samostatne. Silný absolutizmus získava svoju nosnost’

\footnotetext{
${ }^{2}$ Alternatívnymi rozumiem také referenčné rámce, ktoré v istom zmysle reagujú na tie isté podnety, nie sú síce navzájom zlučitel'né (pretože vznikli s rozličnými ciel'mi a zameriavajú sa na odlišné aspekty toho istého podnetu), ale nutne si neodporujú. Aj Carol Rovaneová $(2011,31)$ v tomto duchu spája relativizmus s požiadavkou alternatív, ktoré navrhuje chápat' nie ako pravdy, ktoré nemôžu byt' simultánne prijaté, ale ako alternatívy stojace v normatívnej izolovanosti.

${ }^{3}$ Odlišnú klasifikáciu relativizmov, vystavanú na vzt’ahu závislej a nezávislej premennej (teda toho, čo je relativizované, a toho, vo vzt'ahu k čomu sa relativizuje) možno nájst' u Baghramianovej a Cartera (2020, kap. 1.1).
} 
na základe spleti všetkých troch vláken. Jednotlivými vláknami absolutizmu sú: objektivizmus, fundacionalizmus a univerzalizmus. ${ }^{4}$

Objektivizmus na ontickej úrovni tvrdí, že určité predmety (napr. kamene, stromy, molekuly, atómy) a stavy vecí / fakty (určitá prepojenost' týchto predmetov) existujú nezávisle od referenčných rámcov. Relativizmus, ktorý popiera ontický objektivizmus, naopak tvrdí, že individuácia predmetov a identifikácia stavov vecí sa uskutočňuje vždy a výhradne v konkrétnych referenčných rámcoch. ${ }^{5}$

Fundacionalizmus na ontickej úrovni tvrdí, že čokol'vek existujúce je redukovatel'né na určitú základnú, d’alej neredukovatel'nú, a preto konečnú jednotku. Za týmto tvrdením je idea atomizmu. Napríklad voda je redukovatel'ná na základnú jednotku, ktorou je molekula (vody), skladajúca sa z jedného atómu kyslíka a dvoch atómov vodíka spojených kovalentnými väzbami. Relativizmus oponujúci voči ontickému fundacionalizmu však prichádza s ideou polymorfizmu, ktorá konštatuje závislost’ povahy konečného konštituenta (molekuly vody) od konkrétneho, fundamentálnost' určujúceho rámca. V prípade vody je týmto určujúcim referenčným rámcom chémia, s metódou chemickej analýzy. Idea vychádza z uvedomenia skutočnosti, že predmety a stavy vecí / fakty existujú len na konkrétnej úrovni našich teórií a praxí. Uved’me d'alšie príklady. Stromy a kamene existujú ako stredne vel'ké objekty na úrovni našej bežnej praxe, na úrovni subatomárnych častíc sa s nimi však nestretneme. Život existuje od úrovne jednobunkových objektov, nie na úrovni fotónov. Zvuk sa viaže na prax počutel'nosti, teda psychofyzického vnemu určitého recipienta, ale nenájdeme ho za referenčným rámcom, ktorý sa dá vyjadrit’ pomocou určitej časti spektra mechanického vlnenia vzduchu.

Posledný vláknom absolutizmu je podla Krausza univerzalizmus. Relativizmus útočiaci na túto zložku absolutizmu popiera univerzálnost' reality (presnejšie l'udského prístupu k realite) tým, že akcentuje závislost' individuácie predmetov a konštituovania stavov vecí / faktov od referenčných rámcov. Univerzalista ale namieta, že relativista predsa musí nejako vediet', že dva alternatívne rámce konštituujú ontologicky neuniverzálnu realitu a ak o nich dokáže súbežne premýšl'at' a porovnávat' ich, tak sa tým opätovne dostáva do pozície univerzalizmu. Tu však treba zdôraznit', že relativista s takýmto výkladom nesúhlasí. Byt’ si vedomý dvoch rámcov konštituujúcich konkurenčné ontológie ešte neznamená mat' nejakú univerzálnu ontológiu. Relativistovi celkom stačí, že môže disponovat' tretím referenčným rámcom, ktorého účelom je možnost' porovnat' dva predchádzajúce konkurenčné rámce. Navyše tretí rámec

\footnotetext{
${ }^{4}$ Pozri Krausz $(2011,76$ - 81). Ja sa budem pri predstavovaní troch zdrojov absolutizmu koncentrovat' výhradne na príklady, ktoré sa týkajú ontickej roviny. Dôvodom je, že pojmový relativizmus, o ktorý mi v tomto texte ide, považujem za metafyzickú doktrínu.

${ }^{5}$ Predmety sú z perspektívy ontického relativizmus vlastne mereologickými premennými.
} 
nie je absolútne, ale iba prakticky zvolené kritérium, prostredníctvom ktorého predchádzajúce rámce a ich ontológie porovnávame. $Z$ vyššie uvedeného vyplýva, že druh relativizmu naberá výpovednú hodnotu vtedy, ked’ špecifikuje parametre, ktorých sa týka. Obrát'me teraz pozornost' na druh relativizmu, ktorý sa týka pojmov.

\section{Pojmový relativizmus}

Pojmový relativizmus je jedným variantom relativizmu. Obhajuje stanovisko, že to, čo existuje, ${ }^{6}$ existuje vždy len relativne, inak povedané, vzhl'adom na určitú pojmovú schému, vedeckú teóriu či kategoriálny rámec. ${ }^{7}$ Prívlastok relatívny nás v slovnom spojení pojmový relativizmus odkazuje na súvzt'ažnost', podmienenost' či závislost' jednotlivých pojmov od určitého systému. Treba zdôraznit', že na rozdiel od iných foriem relativizmu - napríklad kultúrny alebo epistemologický relativizmus, ktoré nemusia nutne zastávat' aj stanovisko o existenčnej závislosti entít - je pojmový relativizmus formou metafyzickej doktríny, a to práve na základe obhajoby tvrdenia o existenčnej závislosti. ${ }^{8}$ Kultúrny relativista si totiž dokáže vystačit's relativizmom hodnôt a noriem viazaných na rozličné sústavy konvencií a nepotrebuje súbežne s tým zastávat' aj názor o konštrukcii sociálnych entít. Aj epistemologický relativista môže odolat' pozícii metafyzického relativizmu a koherentne zotrvat' hoci aj na vel'mi chudobnom, ale stále realistickom stanovisku o existencii od nášho myslenia nezávislej a štruktúrovanej reality.

Podla Marie Baghramianovej a Adama Cartera pojmový relativizmus stojí na antirealistickej téze, že „svet sa nám neukazuje hotový, alebo vytesaný; to skôr my zaobstarávame rôzne, a z času na čas nezlučitel'né spôsoby jeho kategorizovania

\footnotetext{
${ }^{6}$ Napríklad: objekt, cicavec, molekula, atóm, zvuk, výška, konajúci, rodič, HDP, spravodlivost', manželstvo, peniaze, podstatné meno či prirodzený jazyk.

${ }^{7}$ Pri predstavovaní rozmanitých druhov relativizmu som jednotne používal spojenie referenčný rá$m e c$, pretože som siahal po čo najneutrálnejšom spojení, ktoré by sa hodilo na všetky domény relativizmu (ontické, epistemické, morálne, právne a iné). V tejto a nasledujúcich častiach textu toto spojenie obmieňam troma d’alšími: pojmová schéma, vedecká teória a kategoriálny systém, a to podl'a toho, o akých typoch pojmov budem hovorit'. Ked' hovorím o klasifikácii biologických druhov, používam výraz kategoriálny systém. V prípade entít týkajúcich sa špeciálnych vied (napr. chémia či fyzika) hovorím o vedeckých teóriách. V prípade príkladov z prirodzeného jazyka a bežnej praxe si vystačím s pomenovaním pojmová schéma.

${ }^{8}$ Rovaneová tiež uvádza, že „relativizmus nie je epistemologická doktrína. Je to metafyzická doktrína, a preto je tak kontroverzná, že sa nedá zachytit' poukazom na nejaký nesporný fakt, ktorý by oponent relativizmu nikdy nepoprel, [fakt] že sme subjektom rôznych epistemických obmedzení, pre ktoré nie sme schopní príst' na to, ktorá strana nesúhlasu sa mýli a ktorá (ak vôbec nejaká) má pravdu. Ak nám má prevládajúci názor pomôct' sformulovat' metafyzickú doktrínu relativizmu, tak musí zachytit' relativizmus [...] nie tak, že ukáže, že my nepoznáme relevantné fakty, ani nie tak, že ich nemôžeme poznat', ale tak, že ukáže, že žiadne relevantné fakty, ktoré by mal niekto poznat', nejestvujú. Toto poukazuje na blízky vzt’ah relativizmu a antirealizmu, z ktorých ten druhý je prinajmenšom nutnou, ak nie postačujúcou podmienkou toho prvého“ (2011,32).
} 
a konceptualizácie“ $(2020,4.2)$. Táto antirealistická téza je vlastne odpoved’ou na otázku Aký je vztah myslenia a reality? Téza pritom akcentuje aktívnu rolu myslenia vo vzt'ahu k realite. ${ }^{9}$ Hovorit' o realite podl'a antirealistu znamená hovorit' o myslenej realite. Táto pozícia nehovorí len o rozličných interpretáciách reality. Akcentuje tvorivý podiel nášho myslenia na samom konštituovaní jednotlivých entít, ktoré sú nám podla antirealizmu k dispozícii vždy a nutne len v rámci určitého systému či pod určitým opisom. ${ }^{10}$ Uvediem príklad. Pavla Kučeru chápeme raz ako otca alebo ako vyššieho, pretože ho vnímame vo vzt'ahu k jeho synovi Jakubovi. Zároveň ho však poznáme ako syna a vzrastom menšieho, pretože ho posudzujeme vo vzt'ahu k jeho otcovi. Raz ako aktéra, pretože o ňom vieme, že ciel'avedome píše poviedku, inokedy ho vnímame len ako jeden z (fyzikálnych) objektov, pretože o ňom uvažujeme v situácii, ked' sa mu od chrbta nevedomky odrazí futbalová lopta. ${ }^{11}$ Pavla Kučeru raz vnímame ako exemplifikáciu cicavca, pretože určujeme jeho taxonomické miesto na úrovni triedy stavovcov, raz ako exemplifikáciu stavovca, pretože berieme do úvahy jeho vlastnosti na taxonomickej úrovni podkmeňa chordátov. Inokedy zasa Kučeru uchopujeme ako časopriestorový objekt, pretože ho chápeme na pozadí fyzikálnej koncepcie časopriestoru. Skrátka podl’a pojmového relativistu v našom porozumení reality niet miesta pre žiadneho číreho, objektívneho či reálneho (rozumej pojmovou

\footnotetext{
${ }^{9}$ Dve dôležité poznámky: 1) tento postoj automaticky negeneruje popieranie kauzálneho pôsobenia reality na našu mysel' / myslenie; 2) aktívny podiel myslenia konkrétneho jednotlivca na formovaní reality je oslabený mierou závislosti jeho myslenia na ním používanom jazyku. Jazyk je totiž štruktúra, ktorá formuje spôsob nášho myslenia a jazyk má totálne sociálnu povahu. Naše myslenie je teda formované jazykom. Spomínam to preto, aby som čitatel'a nezaviedol k domnienke, že rozličné mysle l'udí dokážu mysliet' o realite zásadne odlišne. Mysle l’udí, ktorí zdiel'ajú určitý jazyk, majú výrazne obmedzené možnosti. Na príklade s bežným a mereologickým počítaním sa ukazuje, že štruktúra jazyka (ako zdiel'aného sociálneho nástroja) výrazne obmedzuje možnosti nesúladu našich myslí.

${ }^{10}$ G. E. Anscombová na vyjadrenie tohto faktu používa frázu under description. Fráza indikuje, že akékol'vek entity alebo javy chápeme vždy a nutne určitým spôsobom. „Tupo som zazerala, ked' ma raz niekto vyzval zodpovedat' nasledujúcu otázku: ,Ak môže mat' jeden čin vel'a popisov, čo je tým činom, ktorý má všetky tieto popisy?‘ Táto otázka síce mala niečo naznačovat', nemohla som sa k tomu však dopátrat'. Malo mi hned' dôjst', že stojíme na území ,holých jednotlivín': čo je tým subjektom, ktorý má všetky tieto predikáty? Správnou odpoved’ou na otázku Čo je tým činom, ktorý má všetky tieto popisy? je uviest' jeden z popisov. Ktorýkol'vek, nezáleží na tom ktorý; alebo by asi bolo najlepšie ponúknut' na výber, so slovami Berte ktorýkol’vek, ktorý chcete“ (1979, 220).

${ }^{11}$ Fyzikálne opisy (teda jazyk fyziky) nie sú uspôsobené na opis konania, pretože sa pri nich odhliada od definičného predpokladu konania - na ciel' zameranej vedomej činnosti človeka. Jazyk fyziky je raster, ktorý pri skúmaní a vysvetl'ovaní reality neobsahuje pojmový aparát na odlíšenie živého a neživého, intencionálneho a neintencionálneho, vedomého a nevedomého, takže opisovat' a vysvetl'ovat' konanie človeka môže len na úrovni regularít diania. Z tohto dôvodu sú fyzikalistické vysvetlenia l’udského konania (minimálne v stave súčasných fyzikálnych teórií) nie nepravdivé, ale jednoducho nenáležité.
} 
schémou nezat'aženého) Pavla Kučeru, ktorého by sa dalo chápat' či poznat' odnikial. ${ }^{12}$ Hovorit' o štruktúre reality bez ohladu na podiel výkonu nášho myslenia nedáva z pohl'adu antirealistu zmysel.

$\mathrm{Na}$ podporu antirealistickej pozície pojmového relativizmu, ktorý prisudzuje nášmu mysleniu aktívu úlohu pri formovaní reality, sa často používajú dáta z lingvistiky či príklady z dejín vedy. Rozmanité spôsoby chápania reality, vyjadrené pluralitou opisov a výkladov, sa $\mathrm{v}$ pojmovom relativizme dávajú do súvislosti s rozmanitost’ou jazykových praxí. Prudký rozmach relativistických koncepcií nastal vo vývoji analytickej filozofie najmä $\mathrm{v}$ druhej polovici dvadsiateho storočia - boli sformulované Quinova ontologická relativita, Goodmanov irrealizmus, Putnamov interný realizmus či Kuhnova idea vedeckých paradigiem. Všetky zhodne akcentujú možnost' viacerých, štruktúrou určitej jazykovej praxe podmienených spôsobov opisu a vysvetlenia reality. ${ }^{13}$

Goodmanova idea svetatvorby a Putnamova idea pojmových schém pred nás predkladajú výzvu vysporiadat' sa s existenciou viacerých navzájom nekompatibilných verzií reality. ${ }^{14}$ Odlišné a nekompatibilné verzie reality - u Goodmana rozličné svety, u Putnama rozličné pojmové schémy - sú pritom v oboch prípadoch postavené na idei nedourčenosti obsahu, ktorá zohráva centrálnu úlohu pri výbere jednotlivých pojmových schém. Treba zdôraznit', že v antirealizme Goodmana aj Putnama nedourčenost' hrá iniciačnú rolu pri tvorivom výbere spomedzi viacerých možných, teda alternatívnych pojmových schém. Nedourčenost' / neurčitost' však už v rámci samotných pojmových schém či goodmanovských svetov nemá miesto. $Z$ toho vyplýva, že Goodmanove svety a Putnamove pojmové schémy sú vlastne „axiomatické systémy a sémantické štruktúry, ktoré jednoznačne a presne určujú používanie výrazov“

\footnotetext{
${ }^{12}$ Nedokážeme mysliet' holé jednotliviny, dospievame k nim len na základe určitej analýzy jazyka. K holým jednotlivinám pozri (Schmidt 2011).

13 Tematicky koncentrovaný prehl'ad o napätí medzi realistickými a relativistickými pozíciami v myslení Quina, Davidsona, Putnama a Rortyho prináša Marvan (2014).

${ }^{14}$ Hoci ide o antirealistické pozície, existujú medzi nimi významné odlišnosti. Goodman pokladá existenciu dvoch pravdivých a navzájom nekompatibilných opisov jedného obsahu za dôkaz existencie dvoch rozdielnych a aktuálnych svetov. Dôvodom jeho presvedčenia je, že jeden svet nepripúšt’a dva nekompatibilné fakty, ktoré majú byt' korelátmi pravdy. Oba svety sme podl'a Goodmana vytvorili my. Tým, že sme rozlične konceptualizovali rovnaký obsah, tým sme ponúkli dve rôzne a navzájom nekompatibilné ontológie. Pozri Goodman $(1978,119)$. Putnam s manévrom Goodmana $\mathrm{v}$ princípe súhlasí a chápe ho ako vyvrátenie tézy o jednom správnom a úplnom opise povahy reality. Na rozdiel od Goodmana však z tohto manévra nevyvodí záver o aktuálnej existencii dvoch rozdielnych svetov a zotrvá na skromnejšej pozícii plurality pojmových schém. Zároveň tiež zdôrazní, že nekompatibilita opisov stojí na predpoklade, že jeden z dvojice opisov má v oboch pojmových schémach ten istý význam (čo fakticky nemá). Putnam upozorní aj na d'alší dôležitý fakt, že hoci odlišné pojmové schémy sú výsledkom konvencie, akonáhle sú konvenčne stabilizované, to, čo možno ich prostredníctvom konat', už nie je záležitost'ou konvencie. Porovnaj Putnam $(1987,71)$.
} 
(Kusch 2002, 245). Dôkazom správnosti Kuschovej interpretácie je aj Putnamovo vyjadrenie, že ak v známom príklade dvoch spôsobov (bežného a mereologického) počítania objektov prijmeme napríklad mereologický systém počítania (teda ak vymedzíme intenziu $\mathrm{I}_{1}$ termínu ,objekt“), tak jedinou správnou odpoved’ou na otázku o počte objektov v zátvorke (X X X) bude sedem. A ak si vyberieme bežný spôsob počítania (teda výrazu ,objekt“ priradíme intenziu $\mathrm{I}_{2}$ ), tak jedinou správnou odpoved’ou bude tri. Ukazuje sa, že minimálne v koncepcii Hilary Putnama v pozadí nekompatibility viacerých pojmových schém či pravdivých vedeckých teórií ešte stále stojí idea korešpondencie medzi tvrdeniami a faktami. Je však predpoklad korešpondencie tvrdení a faktov nutný na vysvetlenie a udržanie referenčnej sily jazyka či na vysvetlenie funkčnosti a zmysluplnost' pojmových schém? Nemôže antirealista uskutočnit' manéver, ktorý ho zbaví záväzku chápania pojmovej schémy ako axiomatického systému s fixnou sémantikou? ${ }^{15}$

Jedným riešením by bolo vzdat' sa sémantického predpokladu fixnej extenzie jazykových výrazov, ktorý je garantovaný korešpondenciou medzi realitou (chápanou ako totalita faktov) a jazykom (chápaným ako fixný syntakticko-sémantický systém) a presunút' sa do roviny sociálnej praxe. Do roviny, kde je realita konštituovaná konvenčným používaním určitého súboru znakov. V analytickej filozofii jazyka sa tento manéver uskutočnil vo forme posunu od takzvaných klasických sémantických teórií jazyka k teóriám inšpirovaným sociopragmatizmom. Ak sa presunieme do roviny jazyka chápaného ako spôsob sociálnej zručnosti, tak by sme pre jeden z viacerých správnych opisov reality nepotrebovali fixnú extenziu (v podobe určitého obsahu či definitívneho stavu vecí tam $v$ realite) a stačila by nám len operatívne fixovaná extenzia garantovaná regularitou komunitného používania jazyka. Až týmto krokom by sme sa vlastne odpútali od reprezentacionalistickej predstavy reality ako totality od nás nezávislých faktov. Ak teda pojmový relativizmus neostane v osídlach chápania pojmových schém ako axiomatických a význam jednoznačne určujúcich systémov, tak nemusí trpiet' nedostatkom putnamovského typu antirealizmu ${ }^{16}$ a môže sa pripravit’ na prechod $\mathrm{k}$ chápaniu filozofie ako pojmového inžinierstva.

${ }^{15}$ Martin Kusch $(2002,245$ - 247) na túto otázku odpovedá kladne a dodáva, že ak antirealista nechce príst' o relativistickú pozíciu, tak tento manéver dokonca musí podstúpit'. Ak ho nepodstúpi, neudrží relativizmus. Pojmová schéma $\mathrm{PS}_{1}$ je totiž nekompatibilná s pojmovou schémou $\mathrm{PS}_{2}$ vtedy a len vtedy, ked' poskytuje iný, alternatívny opis toho istého faktu. Tu je však problém, pretože pojmový relativizmus nepripúšt’a ideu reality ako totality faktov. Antirealizmus putnamovského typu pre pojmového relativistu teda neprichádza do úvahy.

${ }^{16}$ Putnamovo a Goodmanovo chápanie pojmových schém pokladám za nedostatočné v tom zmysle, že bráni, presnejšie povedané výrazne obmedzuje možnosti vylepšovania pojmov. Vychádzam z toho, že ak sú pojmy fixné (teda chápané ako nevyvíjajúce sa entity), tak niet priestoru na ich vylepšovanie. V závere textu sa pokúsim ukázat', že zlepšovanie pojmov má pri takomto chápaní pojmových schém značne limitované možnosti, ktoré tkvejú iba v možnosti ich spresňujúceho opisu. 


\section{Filozofia ako pojmové inžinierstvo}

To, že filozofia nejakým zásadným spôsobom súvisí s konceptuálnym priestorom, je pomerne nekontroverzné tvrdenie. ${ }^{17}$ Prax filozofie je už od svojich civilizačných počiatkov spojená s bravúrou vyjadrovania a usmerňovania myšlienok prostredníctvom jazyka. Prax filozofie je praxou používania jazyka. Bez ohl'adu na to, či ide o živé filozofické diskusie, alebo o písomne sformulované filozofické výklady. Filozofi uskutočňujú analýzy, stanovujú definície, formulujú argumenty, konštruujú myšlienkové experimenty, vyvodzujú dôsledky a odkrývajú predpoklady nejakých teórií, a to všetko robia v priestore myslitel’ného vždy prostredníctvom jazyka.

Simon Blackburn v úvode svojej knihy Think (1999) upozorňuje na to, že slová „filozofia“a „filozofovanie“ u mnohých l’udí asociujú nepraktickost'. To, že ide o niečo, čo priamo nesúvisí so svetom. Blackburn preto bystro navrhuje, aby sme filozofiu predstavovali skôr ako pojmové inžinierstvo (conceptual engineering). „Radšej by som sa predstavil tak, že robím pojmové inžinierstvo. Pretože tak ako inžinier skúma štruktúru materiálnych vecí, tak filozof skúma štruktúru myslenia. Porozumenie štruktúre zahŕňa pochopenie toho, ako fungujú časti a ako sú navzájom prepojené. Znamená to vediet', čo by sa stalo, v dobrom aj zlom zmysle, keby sa urobili určité zmeny. To je to, na čo sa zameriavame, ked' skúmame štruktúry, ktoré formujú naše chápanie sveta. Naše pojmy alebo idey formujú mentálne domy, v ktorých žijeme. A my môžeme byt' hrdí na štruktúry, ktoré sme vybudovali, alebo môžeme uverit' tomu, že by sme ich mali rozmontovat' a postavit' nanovo“ (Blackburn 1999, 1). Eleganciu Blackburnovho návrhu predstavenia filozofie vidím $\mathrm{v}$ tom, že problematizuje naivný predpoklad hotovosti sveta, ktorý môžeme vedecky poznat' a technicky vylepšovat' aj bez toho, aby sme o tom zbytočne mudrovali (filozofovali). Rád by som upozornil, že naivný predpoklad o hotovosti sveta je sprevádzaný i d'alšou naivnou predstavou. Predstavou o tom, že jazykom dokážeme zachytit' svet taký, aký skutočne je. A to všetko bez toho, aby sa štruktúra jazyka nejako odrazila na našom chápaní sveta. Blackburnov návrh však nielen problematizuje, ale aj konštruktívne preukazuje kompetentnost' filozofie pri skúmaní aktívneho podielu nášho myslenia na výsledných výkladoch a teóriách sveta. Blackburnov návrh vo filozofickej obci zarezonoval. Od začiatku storočia možno v literatúre vystopovat’ rozmach koncepcií, ktoré sa snažia jednak premysliet' existujúce, jednak navrhnút' nové postupy pojmového inžinierstva. ${ }^{18}$

\footnotetext{
${ }^{17} \mathrm{~K}$ povahe filozofie ako praxe skúmania konceptuálneho priestoru pozri napríklad Zouhar (2015). ${ }^{18} \mathrm{~V}$ odbornej literatúre sa na označenia filozofie chápanej na spôsob Blackburnovho návrhu (1999) používa viacero možných označení. Termín „konceptuálne inžinierstvo“ používajú napríklad Luciano Floridi (2011), Matti Eklund (2015), Herman Cappelen (2018) alebo Sarah Sawyerová (2018, 2020). Tí, ktorí chcú akcentovat' normatívnu stránku danej fillozofickej praxe, teda vylepšovanie našich konceptuálnych nástrojov, siahajú bud’ po označení „melioračné projekty“, napríklad Sally
} 
Čo to teda pojmové inžinierstvo je? Podla Hermana Cappelena pojmové inžinierstvo (d'alej len PI) je ,proces hodnotenia (assessing) a zlepšovania (improving) našich reprezentačných nástrojov“ $(2018,3)$. Cappelen dodáva, že pre tých, ktorí uprednostňujú hovorenie o pojmoch pred hovorením o reprezentačných nástrojoch, je pojmové inžinierstvo vlastne hodnotením a zlepšovaním pojmov. ${ }^{19}$ Obe formulácie pre pozorného čitatel'a otvárajú tú istú otázku. V akom zmysle môžu byt' naše reprezentačné nástroje či pojmy vylepšované? A za danou otázkou sa ukrýva predpoklad, že naše reprezentačné nástroje či pojmy môžu byt' v istom zmysle defektné. Cappelen tento predpoklad odkrýva a konštatuje, že jadro filozofickej práce vidí práve v pokusoch o odstraňovanie miery nevhodnosti toho, ako používame naše reprezentačné nástroje. Filozofovanie na spôsob PI je teda kriticko-tvorivý proces, ktorý je založený na (i) vyjasňovaní a (ii) vylepšovaní našich reprezentačných nástrojov, respektíve pojmov. Prvá čast’ procesu tkvie v určovaní toho, čo naše reprezentačné nástroje aktuálne vyjadrujú. Druhá v navrhovaní stratégií na dosiahnutie toho, aby nami používané reprezentačné nástroje lepšie plnili nami určené ciele. ${ }^{20}$

Dovolím si pripomenút', že obe vyššie spomenuté časti procesu PI nie sú vo filozofii novinkou. Metóda konceptuálnej analýzy, ktorá za svoj ciel' pokladá analýzu a systematizáciu nášho konceptuálneho aparátu, predsa zohrala centrálnu úlohu už pri zrode analytickej filozofie. ${ }^{21}$ Zouhar určuje ciel' metódy konceptuálnej analýzy takto: „odhalit', opísat', prípade konštituovat' vzt'ahy medzi pojmami v rámci určitého konceptuálneho systému“"(2016b, 411). Zdá sa, že tomu, čo Zouhar nazýva opisom vztahov medzi pojmami, zodpovedá to, čo Cappelen (vyhýbajúc sa slovníku pojmov) nazýva hodnotením našich reprezentačných nástrojov. A tomu, čo Zouhar nazýva konštituovaním vzt’ahov medzi pojmami, zasa zodpovedá to, čo Cappelen nazýva zlepšovaním našich reprezentačných nástrojov. Navyše Zouharova dvojica opisu a konštitu-

Haslangerová (2000, 2006), alebo po označení „revizionistické projekty“, napríklad Kevin Scharp (2007, 2013).

${ }^{19}$ To, že Cappelen odmieta slovník pojmov, a pritom dá svojej knihe podtitul Rozprava o pojmovom inžinierstve, samozrejme vyznieva bizarne. Tu je však rozumné vysvetlenie. „Neberte tento názov ako opis: podl'a stanoviska, ktoré $\mathrm{v}$ tejto knihe obhajujem, projekt nie je o pojmoch a nejde tu ani o žiadne inžinierstvo. Napriek opisnej nenáležitosti termínov mám skúsenost', že tento názov vedie pozornost' l'udí správnym smerom, a to je dôvod, prečo som si vybral používanie terminológie Blackburna a Eklunda“" (Cappelen 2018, 4).

${ }^{20}$ Chcem zdôraznit', že ambíciou tohto textu nie je vymedzit' sa voči Cappelenovmu externalistickému návrhu toho, ako sa dá vylepšovanie pojmov uskutočňovat'. Namiesto toho ponúkam vlastný pohl'ad na predpoklady vylepšovania pojmov cez objasnenie povahy pojmových schém.

${ }^{21} \mathrm{~K}$ metóde konceptuálnej analýzy a jej úlohe $\mathrm{v}$ analytickej filozofii pozri Zouhar (2016b), k rozmanitým podobám tejto metódy pozri Kosterec (2016). Mierne skeptický postoj k úspešnosti konceptuálnej analýzy v analytickej filozofii prezentuje Marconi (2019). Zmysluplnost' tejto metódy radikálne odmieta Huemer (2015). 
ovania pojmových vzt'ahov a Cappelenova dvojica hodnotenia a zlepšovania reprezentačných nástrojov pripomína d’alšie osvedčené a vo filozofii bohato zastúpené postupy deskriptívneho a preskriptívneho definovania. Ciel'om deskriptívnych definícií je opis určitého systému, ciel'om preskriptívnych zasa transformovanie jedného systému na druhý. ${ }^{22} Z$ jednodušene povedané, deskripcie a preskripcie pojmových vzt'ahov nielenže sú základom metódy pojmovej analýzy, ale aj pojmového inžinierstva.

Pozrime sa teraz stručne na povahu pojmov a pojmových schém a na ich vzt'ah k jazyku. Podl'a bežne zastávaného a najmenšie kontroverzie vyvolávajúceho presvedčenia pojmy sú základnými stavebnými prvkami myslenia. ${ }^{23} \mathrm{Je}$ teda evidentné, že pojmy sú výsledkom určitej analýzy myslenia. Naše myslenie rozkladáme na jednotlivé myšlienky, tie d'alej na jednotlivé pojmy. Povšimnutiahodná je pritom analogickost' tohto postupu s filozofmi uskutočňovanou analýzou jazyka. Jazyk podobne analyzujeme najskôr na vety, potom na slová (maximálne na významotvorné slabiky). V jadre oboch postupov analýzy leží rovnaký predpoklad. Predpoklad atomizmu, ktorý nás vedie $\mathrm{k}$ rozboru komplexných zmysluplných celkov až po najmenšiu možnú úroveň, ktorá si zachová istú funkciu. Pri oboch analýzach sa zastavujeme až na úrovni minimálneho významu. Nechávame sa viest' predstavou, že na konci analýzy sa niečo ujasní. To, čo pri analýze hl'adáme, je jasné pochopenie úloh jednotlivých častí a ich vzájomného prepojenia. Toto je pravý ciel' metódy konceptuálnej analýzy. Ako však konštatuje Huemer, ,,v dejinách filozofie nebola nikdy vypracovaná správna filozofická analýza“ (2015, 52). Dôvodom obrovskej náročnosti a finálneho zlyhávania metódy konceptuálnej analýzy je podl’a Huemera chybná teória pojmov. ${ }^{24}$

\footnotetext{
${ }^{22}$ Porovnaj Zouhar (2015).

${ }^{23}$ A tu sa aj konsenzus filozofov a psychológov diskutujúcich o povahe pojmov končí. Informatívny prehl'ad o problematickosti povahy pojmov a divergentnosti ich chápania podávajú Margolis a Laurence (2019). Autori ukazujú, že divergentnost' chápania pojmov má svoje príčiny v rozmanitosti prístupov k skúmaniu jazyka a mysle.

${ }^{24}$ Huemerov postreh je v súlade s pozíciou Johna L. Austina, ktorý z chybného prijatia tézy o existencii pojmov viní nesprávny predpoklad, že všetky slová fungujú ako vlastné mená: že ked' používame viackrát to isté slovo, sugeruje nám to falošnú predstavu, že by mal automaticky existovat' jeden a univerzálny objekt, ktorý je týmto slovom označovaný. Austin sa pýta: „A prečo by nemohlo byt' vlastnou funkciou slova označovat' vel'a podobných vecí? Prečo by slová nemali byt' prirodzene ,všeobecné'?“ $(1939,7)$ A na inom mieste dodáva, že d’alšou chybou, ktorá vedie k postulovaniu pojmov, je to, že „namiesto vety, berieme jednotlivé slovo alebo termín, za to, čo má ,význam““ $(1939,9)$. A na inom mieste dodáva ,fráza ,význam slova‘ je nebezpečne nezmyselná fráza. [...] čo jediné má význam je určitá veta. [...] Zdá sa, že zmysel, v ktorom má nejaké slovo alebo nejaká fráza význam, je derivátom zo zmyslu, v ktorom má význam určitá veta. [...] a tak vediet' význam určitého slova alebo frázy znamená vediet’ význam vety, v ktorej sa nachádza“ (1961, 24).
} 
Takzvaná klasická teória pojmov, teória pojmov ako mentálnych reprezentácií (d’alej len KTP), stojí na troch zásadách. Pojmy sú otvorené priamemu introspektívnemu nahliadnutiu, väčšina pojmov je zložená z iných pojmov a definície slúžia na usmerňovanie použivania pojmov. Problém KTP tkvie v tom, že nedokáže vysvetlit' náročnost' ani neuspokojivost' výsledkov analýzy. Pars pro toto: ani po pät'desiatich siedmich rokoch od publikovania trojstranového článku Gettiera nemáme v epistemológii uspokojivú finálnu analýzu (pojmu) poznania. Keby zásady KTP platili, nemali by sme mat' problém dopracovat' sa k základným konštituentom komplexného pojmu poznania. Navyše, ako d’alej vhodne podotýka Huemer, majoritná filozofická prax funguje skôr na uvádzaní príkladov. Podl'a KTP sa človek rozhoduje, či použije určitý pojem, ktorým disponuje, na určitý predmet tak, že „porovná vlastnosti tohto predmetu s vlastnost’ami vymenovanými v definícii tohto pojmu. Filozofická prax je však opačná. Najprv len vel'mi intuitívne posúdime, či sa nám určitý pojem hodí na určitý predmet, nezávisle od akejkol'vek definície. A až potom hodnotíme definíciu podl'a toho, ako dobre zodpovedá správne použitému pojmu“ $(2015,53)$. Súhlasím s Huemerom v tom, že metóda konceptuálnej analýzy, ktorá je postavená na reprezentacionalistickej KTP, odkrývajúcej koherentné univerzum pojmov, zlyháva. KTP totiž nevysvetluje proces reálneho fungovania a konštituovania významov jazyka. To, čo robí, je skôr opis idealizovaného jazyka či predpis správneho myslenia. Vrát’me sa však $\mathrm{k}$ meritu veci a opýtajme sa, ako by sme mali chápat' pojmy a pojmové schémy, aby sme mohli uvažovat' o ich vylepšovaní?

$\mathrm{Na}$ konci druhej časti tohto článku som sa síce priblížil k dvojakému výkladu pojmovej schémy, doteraz som ale neobjasnil, čo to pojmová schéma vlastne je. Na účely tohto textu podla mňa celkom stačí siahnut' po Quinovom lakonickom vymedzení pojmovej schémy ako určitej „štruktúry vel'kej množiny viet.“"25 Ale prečo definovat' pojmové schémy pomocou množiny viet? Jednoducho preto, že pojmové schémy možno zachytit' pomocou množiny viet. Aj napriek jednoduchosti sa z tohto priblíženia dá extrahovat' to, že pojmová schéma je (i) určitý celok, (ii) zložený z významových častí, (iii) medzi ktorými sú určité vzt’ahy podmienenosti, ktoré z tohto celku robia systém. ${ }^{26}$ Pojmová schéma sa pre tieto charakteristiky v literatúre prirovnáva $\mathrm{k}$ sieti, v rámci ktorej vystupujú jednotlivé pojmy ako priesečníky myšlienok.

${ }^{25}$ Citované podl'a Marvana $(2014,131)$ z rozhovoru medzi W. V. O. Quinom a Yasudikom Tomidom, ktorý vyšiel v práci Quine and the Contemporary American Philosophy. Ed. by Y. Tomida. Kyoto: Sekaishisosha, 1994, 4 - 51.

${ }^{26}$ Podobné priblíženie prináša aj Zouhar: „Konceptuálny systém je vymedzený pomocou niekol’kých zložiek: (i) množiny základných (primitívnych, nedefinovaných) pojmov, (ii) množiny odvodených pojmov a (iii) množiny rozmanitých pojmových vzt'ahov. Tieto pojmové vzt'ahy zachytávajú napríklad to, že určité pojmy sú definované pomocou iných pojmov; to, že určité pojmy sú explikované pomocou iných pojmov; to, že určité pojmy sú všeobecnejšie ako iné pojmy atd'. Vd'aka 
Ak je toto prirovnanie správne, tak z neho zároveň vyplýva, že pojmy nemajú mimo siete myšlienok žiadnu samostatnost' a sú plne určené až $s$ ohl'adom na celok (alebo na významnú čast') toho-ktorého systému. Ak sú pojmy bodmi pojmových schém a ak ležia na priesečníkoch našich myšlienok, tak návrh vidiet' filozofiu ako pojmové inžinierstvo, ktorého úlohou je vylepšovanie pojmov, stojí pred vážnou otázkou: Ako možno vylepšovat' body či priesečníky?

\section{Záver}

Ak si uvedomíme plnú závislost' (teda relatívnost') pojmov od pojmových schém, je zrejmé, že vylepšovat' pojmy nemožno bez prebudovávania celkov. Ukázali sme, že pojmový relativizmus putnamovského typu, ktorý počíta s pluralitou alternatívnych pojmových schém, považuje pojmové schémy za fixne stabilizované systémy pevne určených vnútorných vzt’ahov (podl'a Kuscha ide o chápanie pojmovej schémy ako axiomatické systému). Takáto interpretácia pojmovej schémy však filozofovi, ktorý chce naplnit' ciele pojmového inžinierstva, poskytuje vel'mi obmedzené možnosti. Umožní mu pojmy bud' len vyjasňovat' (tým, že opíše polohu pojmov v rámci fixnej schémy), alebo ich aj obmedzene vylepšovat' (tým, že mu umožní obohatit' či rozšírit' existujúci fixný systém o nejaký nový pojem). ${ }^{27} \mathrm{~V}$ metafore siete danému kroku vylepšenia zodpovedá zhustenie siete formou pridania nového vlákna (nie nového uzla!). Tento krok posilní pevnost' celkovej siete, ale nezruší pôvodnú štruktúru. S takto posilnenou siet'ou sme zvyčajne schopní ulovit' viac (filozofických) rýb. Subtílnejšie pojmové dištinkcie v existujúcich schémach nám prosto umožňujú komplexnejšie zachytit' realitu.

Ak ale nemáme záujem len o rozširovanie inak fixných systémov, ale pomocou PI chceme zlepšovat' pojmy zásadnejším spôsobom, tak potrebujeme iné chápanie pojmových schém. Chápanie, ktoré bude vychádzat' z principiálnej otvorenosti, a nie

tomu, že konceptuálny systém obsahuje aj pojmové vzt’ahy, možno si každý takýto systém predstavit' ako určitú siet', v ktorej jednotlivé body - pojmy - sú rôznymi spôsobmi poprepájané s inými bodmi. Konceptuálny systém možno vyčerpávajúco opísat’ pomocou výrokov či tvrdení zachytávajúcich zložky spomenuté v (i) - (iii)“"(2016b, 412).

${ }^{27}$ Zouhar uvádza: „Môže sa zdat', že konštituovanie nových vzt'ahov medzi pojmami je problematické. V prípade, že pojmy budeme považovat' za nevyvíjajúce sa abstraktné entity, konštituovanie nových vzt’ahov neprichádza do úvahy, ked’že sa predpokladá, že pojmy v konceptuálnom systéme sú ,hotové', a to (okrem iného) znamená, že musia mat'už jednoznačne špecifikované vzt’ahy $k$ iným pojmom daného systému. [...] Táto úvaha je v princípe správna, no predsa len existujú určité vzt'ahy medzi pojmami, ktoré možno zaviest' aj v prípade, že konceptuálny systém obsahuje už ,hotové pojmy - ide o vzt’ahy, ktoré závisia od určitých konvencií, dohôd či rozhodnutí (a teda vzhl'adom na pojmy nejde o konštitutivne vzt’ahy). Jedným takýmto vzt’ahom je definičný vzt’ah v prípade tzv. preskriptívnej definície. [...] Iný spôsob, ako konštituovat' nový vzt’ah, spočíva v tom, že sa do konceptuálneho systému zavedie nový pojem, pre ktorý sa zároveň zavedú aj konceptuálne vzt'ahy s niektorými pôvodnými prvkami konceptuálneho systému“ (2016b, 412). 
z nemennosti pojmových schém. V principiálne otvorenej kompozícii pojmových schém majú aj pojmy len operatívnu, dočasne stabilizovanú povahu. „Odmietnut’ pojmové schémy ako monolitické a determinované systémy významov samozrejme neznamená vzdat' sa pojmovej relativity (a tým antirealizmu). Namiesto toho treba presadzovat' inú formu pojmovej relativity. Takú formu pojmovej relativity, ktorá kladie dôraz na skutočnost', že súčasné použitie akejkol’vek klasifikácie je vždy určené kontingentnými a lokálnymi záujmami a ciel'mi a že budúca cesta akejkol’vek klasifikácie je principiálne otvorená“ (Kusch 2002, 246). Projekt filozofie ako PI potrebuje namiesto sémantických teórí teórie metasémantické. ${ }^{28}$ Teórie, ktoré vysvetlia, ako sa sémantické hodnoty našich jazykových výrazov menia naprieč časom. Antirealizmus je pritom nutnou podmienkou pojmového relativizmu a pojmový relativizmus zasa predpokladá relatívnost' pojmov vzhl'adom na celky. Ak sú pojmy chápané ako nemenné, teda presne a fixne určené (objektívne, fundamentálne, univerzálne), tak sa vylepšovacia čast' projektu filozofie ako pojmového inžinierstva dá uskutočňovat' len vel'mi limitovane. Ukazuje sa teda, že pojmový relativizmus je nutnou podmienkou vylepšovacej časti pojmového inžinierstva a explicitná podoba argumentu v prospech tejto tézy môže mat' nasledujúcu podobu.

1. Pojmy sú nutnou súčast’ou pojmových schém, teda neexistujú samostatne.

2. Pojmové inžinierstvo má za ciel' pojmy nielen opísat', ale ich aj zlepšovat', teda menit'.

3. Pojmové inžinierstvo môže menit’ pojmy iba v rámci pojmových schém, nie izolovane.

4. Pojmové schémy môžeme vnímat' dvojako, bud' (A) ako fixne uzavreté (axiomatické) alebo (B) ako operatívne uzavreté (otvorené postupnej revízii naprieč časom).

5. V (A) schémach sú pojmy chápané fixne - ako nevyvíjajúce sa -, čo neumožňuje ich zmenu (azda len spresňovanie).

6. V (B) schémach sú pojmy chápané ako vyvíjajúce sa, čo umožňuje ich zmenu.

7. Plnohodnotné zlepšovanie pojmov v pojmovom inžinierstve umožňuje len (B) chápanie pojmových schém, ktoré relativizmus pojmov nespája len s ideou plurality schém, ale počíta s relativitou ako internou vlastnost'ou pojmov v rámci každej jednej pojmovej schémy.

8. Pojmová relativita (chápaná ako relativita pojmov v rámci schém pripúšsłajúcich revíziu) je nutnou podmienkou pojmového inžinierstva (ktoré má ambíciu zlepšovat' pojmy).

${ }^{28}$ Rozdiel medzi sémantickými a metasémantickými teóriami významu pozri v práci Speaks (2019). 
Pojmová schéma je určitým logicky koherentným systémom presvedčení, ktoré sa dajú vyjadrit' vetami. Ak sú pojmové schémy axiomatické (fixné sústavy presvedčení), tak je zlepšovanie pojmov obmedzené len na spresňujúce opisy pojmov. Je uskutočnitel'né tak, že k fixným presvedčeniam doplňujeme d'alšie, ktoré sú v súlade s ostatnými tvrdeniami, bez zmeny tých pôvodných. Ako som už povedal vyššie, takýto typ vylepšovania pokladám za značne limitovaný. Treba tiež akcentovat', že pojmový relativizmus nechápem len ako tézu o pluralite pojmových schém, ale aj ako tézu o internej relatívnosti pojmov $\mathrm{v}$ rámci operatívne otvorených pojmových schém.

Celkom na záver chcem zdôraznit', že jazyk formuje naše myslenie a sprostredkúva náš svet. Je živým a otvoreným systémom. To, že sa doň rodíme a vrastáme, a to, že na posun významov výrazov jazyka máme len vel’mi obmedzený dosah, by nás nemalo viest' $\mathrm{k}$ predstave o plnej určenosti či nemennosti jazyka. Uvažovat' o tom, že významy jeho zložiek by boli fixné aj v nejakom silnejšom ako v prakticko-operatívnom zmysle, podl'a mňa nie je správne. Goethe raz povedal, že architektúra je zamrznutá hudba. Spengler, že gotika je výrazom bukových lesov. Ja dodávam, že pojmové schémy sú gotické katedrály, ktoré sa pokúšajú zachytit’ pulzujúcu hudbu nášho jazykového ekosystému.

\section{Literatúra}

ANSCOMBE, G. E. M. (1979): Under a Description. Noûs, 13 (2), 219 - 233. DOI: https://doi.org/10.2307/2214398

AUSTIN, J. L. (1939): Are There A Priori Concepts? Proceedings of the Aristotelian Society, Supplementary Volume 18, $83-105$.

AUSTIN, J. L. (1961): The Meaning of Word. In: Urmson, J. O. - Warnock, G. J. (eds.): J. L. Austin. Philosophical Papers. London: Oxford University Press, 23 - 43.

BAGHRAMIAN, M., CARTER, A. J. (2020): Relativism. In: Zalta, E. N. (ed.): The Stanford Encyclopedia of Philosophy. Dostupné na: https://plato.stanford.edu/archives/fall2020/entries/relativism/ (Navštívené: 31. 10. 2020).

BLACKBURN, S. (1999): Think. A Compelling Introduction to Philosophy. Oxford: Oxford University Press.

CAPPELEN, H. (2018): Fixing Language. An Essay on Conceptual Engineering. Oxford: Oxford University Press.

EKLUND, M. (2015): Intuitions, Conceptual Engineering, and Conceptual Fixed Points. In: Dale, Ch. (ed.): The Palgrave Handbook of Philosophical Methods. Palgrave: Macmillan, 363 - 385. DOI: https://doi.org/10.1057/9781137344557_15

FLORIDI, L. (2011): A Defence of Constructionism: Philosophy as Conceptual Engineering. Metaphilosophy, 42 (3), $282-304$.

GOODMAN , N. (1978): Ways of Worldmaking. Indianapolis: Hackett Press.

HASLANGER, S. (2000): Gender and race: (what) are they? (what) do we want them to be? Nôus 34 (1): 31 - 55. DOI: https://doi.org/10.1111/0029-4624.00201

HASLANGER, S. (2006): What good are our intuitions? Philosophical analysis and social kinds. Aristotelian Society Supplementary, 80 (1), 89 - 118. DOI: https://doi.org/10.1111/j.14678349.2006.00139.x 
HUEMER, M. (2015): The Failure of Analysis and the Nature of Concepts. In: Dale, Ch. (ed.): The Palgrave Handbook of Philosophical Methods. Palgrave: Macmillan, 51 - 76. DOI: https://doi.org/10.1057/9781137344557_3

KOSTEREC, M. (2016): Methods of Conceptual Analysis. Filozofia, 71 (3), 220 - 230.

KRAUZ, M. (2011): Varieties of Relativism and the Reach of Reasons. In: Hales, S. D. (ed.): A Companion to Relativism. Oxford: Wiley-Blackwell, 70 - 84.

KUSCH, M. (2002): Knowledge by Agreement. The Programme of Communitarian Epistemology. Oxford: Clarendon Press.

MARCONI, D. (2019): Analysis as Translation. Topoi, 38 (2), 347 - 360. DOI: https://doi.org/ $10.1007 / \mathrm{s} 11245-016-9420-1$

MARGOLIS, E., LAURENCE, S. (2019): Concepts. In: Zalta, E. N. (ed.): The Stanford Encyclopedia of Philosophy. Dostupné na: https://plato.stanford.edu/archives/sum2019/entries/concepts/ (Navštívené: 31. 10. 2020).

MARVAN, T. (2014): Realismus a relativismus. Praha: Academia.

PUTNAM, H. (1987): Truth and Convention: On Davidson's Refutation of Conceptual Relativism. Dialectica $41(1-2), 69-77$.

ROVANE, C. (2011): Relativism Requires Alternatives, Not Disagreement or Relative Truth. In: Hales, S. D. (ed.): A Companion to Relativism. Oxford: Wiley-Blackwell, 31 - 52. DOI: https://doi.org/10.1002/9781444392494.ch2

SAWYER, S. (2018): The Importance of Concepts. Proceedings of the Aristotelian Society, 118 (2), 127 - 147. DOI: https://doi.org/10.1093/arisoc/aoy008

SAWYER, S. (2020): The Role of Concepts in Fixing Language. Canadian Journal of Philosophy, 50 (5), 555 - 565. DOI: https://doi.org/10.1017/can.2020.5

SCHARP, K. (2007): Replacing Truth. Inquiry, 50 (6), 606 - 621. DOI: https://doi.org/ 10.1080/00201740701698589

SCHARP, K. (2013): Truth, the Liar, and Relativism. Philosophical Review, 122 (3), $427-510$.

SCHMIDT, M. (2011): Holé indivíduá - kritika zvnútra. Organon F, 18 (1), 96 - 101.

SPEAKS, J. (2019): Theories of Meaning. In: Zalta, E. N. (ed.): The Stanford Encyclopedia of Philosophy. Dostupné na: https://plato.stanford.edu/archives/win2019/entries/meaning/ (Navštívené: dátum).

ZOUHAR, M. (2016a): Filozofia a konceptuálny priestor. In: Javorská, A. - Kocinová, L. - Wagnerová, S. (eds.): (Meta)Filozofia - Prax. Bratislava: SAV, 51 - 56.

ZOUHAR, M. (2016b): Konceptuálna analýza v analytickej filozofii. Filozofia, 71 (5), 410 - 424.

ZOUHAR, M. (2015): Metóda definovania. Filozofia, 70 (4), 258 - 271.

Článok vznikol ako súčast' riešenia grantového projektu VEGA č. 1/0640/19 s názvom Pojmový relativizmus $v$ súčasnej filozofii: vymedzenie, limity a problémy.

Pavol Labuda

Katolícka univerzita v Ružomberku

Filozofická fakulta

Katedra filozofie

Hrabovská cesta 1B

03401 Ružomberok

Slovenská republika

e-mail: pavol.labuda@ku.sk

ORCID: https://orcid.org/0000-0001-5522-435X 